Whitty, M. (2002). Possible selves: Exploring the utility of a narrative approach. Identity: An International Journal of Theory and Research, 2(3), 213-230.

Possible selves: An exploration of the utility of a narrative approach Dr. Monica Whitty 


\section{Possible selves: An exploration of the utility of a story-writing approach}

This study has two main aims: (a) to explore young men and women's hopes and dreams for the future and (b) in so doing to explore the utility of a story-writing method. It is argued here that when identity is conceptualized as a life story, researchers need to consider story-writing methods in their investigations of identity formation. Three methods were used to compare findings from the story-telling method with more traditional methods, in this case an interview and a questionnaire. This research revealed that the story-writing method was useful for a variety of reasons. It provided rich data that generated themes that were taken up by the following methods. Moreover, it was more successful than the other methods at bringing to light subjects' 'ideal selves'.

Keywords: story-writing, narrative, identity, ideal selves, hopes and dreams. 
Various methods have been employed to investigate future aspirations. The most popular choice of method used to study people's hopes and dreams has been either a questionnaire (e.g., Kalakoski \& Nurmi, 1995; Nurmi, Poole, \& Katakoski, 1994; Nurmi, Seginer, \& Poole, 1990) or an events listing approach (e.g., Poole \& Cooney, 1987). Some researchers have elected to use interviews; for example, the intensive interview technique developed by Levinson $(1978,1996)$. However, in the main, most researchers have opted for the quick and cost efficient questionnaire.

The research presented in this article draws from a much larger study that examined young people's hopes and dreams for the future. The focus here is on the effectiveness of a story-writing approach in this investigation. The utility of this storywriting approach is assessed by comparing results obtained from an interview method and a questionnaire. More specifically, I focus on on age and sex differences in young people's dreams, and compare the findings yielded from each method. If, as is argued here, identity is a life story, then using narrative techniques to investigate people's hopes and dreams could be of great benefit to researchers.

\section{Identity is a life story}

Over the past 20 years, there has been a growing interest in examining people's stories of their own lives (e.g., Bruner, 1986, Cohler, 1982; Gergen \& Gergen, 1987; Mair, 1990; McAdams, 1989, 1993, 1996; Ochberg, 1994; Polkinghorne, 1988; Sarbin, 1986). Such theorists have proposed that human beings are storytellers by nature, and that stories are a natural way to report experience. For example, Sarbin (1986) suggested that almost everything of interest in psychology is narrative. In fact, he proposed that narrative may be a 'root metaphor' for psychology as a whole. Sarbin argued that to know a person one must know the story in which that person is 
participating. Making sense of others requires knowledge of their subjective experience. Mair (1988) also suggested that psychology is approached as a storytelling discipline. He claimed that we live in and through our stories. Mair (1988) stated that the only world we can know is a story world. Moreover, Howard (1991) argued that:

We are in the process of creating value in our lives - of finding the meaning of our lives. A life becomes meaningful when one sees himself or herself as an actor within the context of a story - be it a cultural tale, a religious narrative, a family saga, the march of science, a political movement, and so forth (p. 196).

Many narrative psychologists are more concerned with what people 'say', than what they 'do'. Bruner (1987) has proposed that "Narrative imitates life, life imitates narrative. 'Life' in this sense is the same kind of construction of the human imagination as 'a narrative' is" (p. 13). In addition, Ricoeur (1984) has argued that there seems to be no other way of describing 'lived time' except in the form of narrative. Even if we were to give a brief account of events that have happened to us, these events would be chosen according to who we now see ourselves to be and thus would take place in the form of narrative. He argued that we do not copy reality (i.e., recall the empirical facts) but rather give a new reading of events. Other theorists such as Neisser and Fivush (1994) have taken a similar line of argument, stating that it is important to recognize that narratives are not fixed or static, but rather change with every re-telling.

The stance taken in this article is that it is important to recognize, in line with the theorists cited previously, that the stories people construct about their lives are influenced by how they see themselves at a particular point in time. In particular, Dan McAdams' understanding of identity is drawn from in this current research. McAdams 
has focused of the stories that individuals construct. He has used the term 'personal myth' to describe the stories people create when forming their identity. In essence, a 'personal myth' is "an act of imagination that is a patterned integration of our remembered past, perceived present, and anticipated future" (McAdams, 1993, p.12). The personal myth does not change dramatically from day to day, but rather will undergo transformations over time (McAdams, 1996). Therefore, the early memories we recall can be considered an indication of our present understanding of the self. We choose in our present lives to remember particular events in our past in a certain way. Likewise, we select possible future scenarios depending on how we see ourselves in our current lives. This means that stories of the self can change with each re-telling depending on who one understands oneself to be in the present. Our memories of the past and our projections of the future are not fixed. Identity is a life story. In accordance with this view, I explore the utility of a story-writing method in the investigation of young people's hopes and dreams for the future.

\section{Measuring hopes and dreams}

This current research investigates one aspect of the personal myth - individuals' narratives of their future lives. Past research on hopes and dreams has focused primarily on individuals in their mid-teens. Given that identity is neither determined nor fixed by the end of adolescence, there is a need to examine individuals' dreams beyond mid-adolescence. Although adolescence is an appropriate developmental stage to examine in terms of life choices, there is also a need to focus research beyond adolescence, in light of the substantial changes that are still occurring in the lives of young adults (Clausen, 1995). Hence, in this study I elected to examine young adults' hopes and dreams for the future and the impediments they foresee to these dreams. 
No standardized narrative method exists for conducting narrative research. For example, some researchers prefer to use biography, whereas others prefer a storywriting technique. Although some narrative techniques, such as the 'sentence completion test' (e.g., Agarwal \& Tiwari, 1988) and Levinson's (1996) intensive interview technique have been used by researchers when investigating people's hopes for the future, these techniques are not common. It is proposed here that although narrative techniques are more time consuming, they can present a richer picture and give greater insights into the construction of identity than other, more traditional methods.

In examining the usefulness of a story-writing methodology in the investigation of young people's hopes and dreams for the future, I compared three methods in this article: (a) a questionnaire method, (b) an interview method, and (c) a story-writing method. Usefulness was determined by how adequately each method was able to evaluate how young people would 'like' to see their future lives.

In our quest to determine the most appropriate techniques to examine the life story, we also need to consider the different types of 'selves' that various methods might be measuring. Markus and Nurius $(1986,1987)$ have developed a theory about 'possible selves'. They argued that the three possible selves include: the 'expected self', the 'hoped for self', and the 'feared self'. The 'expected self' is the person one believes one can realistically become. According to these theorists, the 'expected self' acts as the focal point for one's energies in striving for the future. In contrast, the 'hoped for self' is farther away from what the self presently is. The 'hoped for self' may or may not be realistic. Finally, the 'feared self' is a possible self that one does not desire to become. The 'feared self' serves as a motivator, so that the individual 
takes action to avoid that possible self. In this paper, it is the 'hoped for self' that is investigated.

In addition, I take account of Higgins and his colleagues' (Higgins, 1987; Alexander \& Higgins, 1993; and Strauman \& Higgins, 1987) distinction between the different aspects of the self. They proposed that we need to consider three selves: an 'actual self', an 'ideal self' and an 'ought to self'. The 'actual self' is the representation of how you or another actually believes you are; the 'ideal self' is the representation of how you or another would like to see yourself, including hopes and wishes for you; and the 'ought to self' represents the attributes that you believe you should possess. It is not always clear whether researchers are tapping into actual selves, ideal selves or ought to selves, when they are investigating people's future lives. For example, a teenage girl who is asked to list her hopes and fears for the future might be writing the hopes she thinks that as an adolescent female she ought to have. I am interested in how effective the three different methods are at elucidating the 'ideal' self in respect to young people's hopes for the future.

\section{Aims of this research}

This study contributes to the research that has investigated people's hopes and dreams fro the future by examining age and sex differences in young people's dreams.

Past studies of people's hopes, dreams, and concerns for the future have focused mainly on adolescence (e.g., Gillies, 1989; Greene, 1986; Greene \& Wheatley, 1992; Nurmi, Poole, \& Seginer, 1995; Seginer, 1992; Trommsdorff, Lamm, \& Schmidt, 1979) because it is at this age the transition from childhood to adulthood occurs. The onset and completion of adolescence is typically are defined by biological and social changes, which makes the actual age range for this period somewhat fuzzy; 
however, most research concentrates on the secondary school years, from ages 13 to 18. In respect to hopes and dreams studies, few studies have moved beyond midadolescence to examine the transition period from late adolescence into adulthood. I attempt to redress this omission by examining the hopes and dreams of older adolescents (17-22 years) and young adults' (28-33 years) hopes and dreams.

In line with past research, sex differences are also considered. For example, Roberts and Newton's (1987) review of four unpublished dissertations based on Levinson's theory found that, unlike those of men, women's Dreams were usually split between occupational and interpersonal goals. Other studies of adolescents' dreams have found that boys tend to be more interested in material dreams, whereas girls are more interested in dreams relating to future family (Nurmi, 1991). Accordingly, I explicitly examine sex differences in young adults' dreams and obstacles to these dreams.

Towards this end, several methods were employed so that findings from the story-telling method could be compared with those from an interview and questionnaire method. The story-writing method was the first method used, next an interview was constructed in light of the themes generated from the story-writing method, and finally a questionnaire was constructed out of the themes generated from the first two methods. Although the sequence of methods employed could indeed influence the final assessment of the benefit of each method, it was the preferred means to generate the maximum amount of themes, without limiting the scope of the research too early in the study. Therefore, the main aim of this paper is to explore the value of a story-writing method in the investigation of young people's hopes and dreams. Because of the breadth of data collected from the three methods reported here, it is impossible to report all of the results. Hitherto, the results that relate to answering 
the main research question of the utility of a story-writing method are included in this article.

\section{METHODS}

A multi-method approach was employed to research young people's hopes and dreams for the future. For the first study a story-writing method was devised, in the second study interviews were conducted, and in the third study a survey was administered.

\section{Study 1: Story-writing}

Participants first completed a short questionnaire asking for their demographic details. Then they were asked to write a story about how they would like to see themselves in 10 years time. They were given an hour to complete the task, although most participants took about 40 minutes to write their stories. The instructions were as follows:

Write a story about how you would like to see yourself in the next 10 years. Write the story in the third person. Include as much detail as possible and particularly avoid censoring details that seem irrelevant. Avoid psychological interpretation. Include any obstacles that get in the way of achieving your dreams/goals. Produce the most vivid story about how you will achieve your dreams/goals.

These instructions were devised drawing from past studies that have asked adolescents to write essays about their future. For example, Gillespie and Allport (1955) and Mönks (1968) had their subjects write essays anticipating their futures entitled "From 
now to 2000 A.D." Poole (1983) had respondents write down how their lives would be in 10 years time. They were asked to write an essay on the following topic:

Myself in ten years' time: e.g. what kind of job you'll have, whether or not you'll be married, the kind of person you'd like to marry, where you'll live, what kind of person you'll be, what kinds of things you'll be doing, etc. (Poole, 1983, p. 238).

This seemed an appropriate focus for the narrative approach. However, I decided to exclude from the instructions suggestions of themes to focus on, so as not to close off themes that might emerge in the stories. Furthermore, I was interested in the obstacles that participants foresaw in relation to their dreams; thus, the directions requested participants to write the obstacles to their dreams. In addition, some concepts from memory work (Crawford, Kippax, Onyx, Gault, \& Benton, 1992; Haug, 1987) were considered in developing the instructions. A content analysis was carried out to clarify the number and types of dreams and impediments included in their stories.

Participants. The sample consisted of 140 men and 140 women from Sydney, Australia. Two age groups were included: 140 participants were $17-22$ year olds $(\underline{M}=$ 19.0, $\underline{\mathrm{SD}}=1.61)$, and 140 participants were $28-33$ year olds $(\underline{\mathrm{M}}=29.9, \underline{\mathrm{SD}}=2.02)$.

First year psychology students from two universities participated in this study. Other groups who participated included: students' friends; social groups; and people attending two of Sydney's markets (one in the inner city, and the other located in the outskirts of Sydney).

In this sample, 3\% had achieved a high school education, $9 \%$ had a school certificate, $5 \%$ had technical qualifications, $54 \%$ had completed the higher school certificate (year 12), $23 \%$ had a degree or diploma, and $7 \%$ had achieved postgraduate qualifications. Although this sample is a little skewed towards the better educated, it is 
a reasonably good representation of the Australian population. In May 1997a (close to the time this sample was obtained), the Australian Bureau of Statistics reported that of 15-34 year olds, $46.0 \%$ had not completed the Higher School Certificate, 32.3\% had completed the higher school certificate, $21.7 \%$ had post-school qualifications. It should be noted that $24.9 \%$ of the ABS population (considering it begins at 15 years) were still at school. When we consider that the age groups are somewhat different, with more people expected to be at school in the ABS population, the sample appears to be representative of the population.

Table 1 indicates that this particular sample is more skewed toward professionals and intermediate clerical workers/salespeople/personal service workers (ABS, 1997b). Those not included in the table were either students or unemployed.

Finally, $89 \%$ of the sample were born in Australia, another $2.5 \%$ came from English speaking countries, and 9\% came from non-English speaking countries.

Table 1

Percentages for participants' occupations

\begin{tabular}{lll}
\hline Occupation & $\begin{array}{l}\mathbf{n}=\mathbf{1 9 7} \\
(\mathbf{\%})\end{array}$ & $\begin{array}{l}\text { ABS } \\
(\mathbf{\%})\end{array}$ \\
\hline Managers & 11.2 & 7.5 \\
\hline Professionals & 27.4 & 17.5 \\
\hline Trades People & 10.2 & 13.6 \\
\hline $\begin{array}{l}\text { Clerical/personal service } \\
\text { workers }\end{array}$ & 45.2 & 31.8 \\
\hline Laborers & 2.5 & 10.1 \\
\hline Plant Operators/drivers & 0.5 & 9.1 \\
\hline Paraprofessionals & 3.0 & 10.4 \\
\hline
\end{tabular}




\section{Study 2: Interviews}

Instrument. In the second study, a semi-structured interview schedule was used. Participants were questioned about the specific dreams that emerged in Study 1; however, the interview also allowed for flexibility to concentrate on dreams that participants considered important.

As in Study 1, the interview schedule asked participants to focus on how they would like to see themselves in 10 years time. Demographic details were collected again. Questions were also included about dreams that participants had already formed and tried to live out. Participants first were requested to describe the dreams they had for the next 10 years, in as much detail as possible. Then they were asked to explain how they might go about achieving these dreams and to consider any obstacles they foresaw to achieving these dreams. These interviews were audio taped and transcribed for analysis.

Participants. The sample for the interview method was recruited from similar groups to that used in Study 1, including university students, people attending markets and social groups. It consisted of 24 men and 24 women from Sydney, Australia, of whom 24 were $17-22$ year olds $(\underline{M}=20.5, \underline{S D}=1.5)$ and 24 were $28-33$ year olds $(\underline{M}=30.6$, $\underline{\mathrm{SD}}=1.8)$

Of these, $4 \%$ had achieved a school certificate (year 10), 52\% had achieved their higher school certificate, $8 \%$ had achieved technical qualifications, $13 \%$ had achieved a diploma, 20\% had achieved a degree, and 3\% had achieved postgraduate qualifications. 
The participants' occupations included: $8.3 \%$ managers, $16.7 \%$ professionals, $4.2 \%$ trades people, $18.8 \%$ clerical positions, $22.9 \%$ salespeople or personal service workers, $6.3 \%$ laborers, $10.4 \%$ paraprofessionals, and $12.5 \%$ were students or unemployed.

Ninety-two percent of the sample were Australian born, $2.1 \%$ of the sample were born in English speaking countries, and $6.3 \%$ of the sample were born in nonEnglish speaking countries.

\section{Study 3: Questionnaire}

Instrument. The main themes and sub-themes that emerged from the previous studies were used in the questionnaire (see author for copy of questionnaire). The 'futureorientation questionnaire' (Nurmi, et al., 1990) was also drawn from to assist in the wording of the questionnaire. As in the Future-Orientation Questionnaire, this questionnaire asked 'how important' are particular dreams, and 'how often' they thought about these dreams. However, to be consistent with Study 1 and Study 2, the questionnaire asked respondents to consider themselves in 10 years time. Most of the questionnaire took the form of forced-choice questions, typically on a 5-point Likert scale. For example, respondents were asked: In ten years time, how important will a career be to you? The responses were based on the following: 1 (not at all important), 2 (not very important), 3 (somewhat important), 4 (rather important), and 5 (extremely important). An open-ended question inviting respondents to add any further comments to the questionnaire once they had completed it. 
Participants. In an attempt to obtain consistency in each of the samples, participants used in Study 3 were again recruited from similar groups including university students, and social groups. The sample consisted of 100 men and 100 women from Sydney, Australia, of whom 100 were $17-22$ year $(\underline{M}=19.5, \underline{S D}=1.7)$ and 100 were 28 - 33 year olds $(\underline{\mathrm{M}}=29.2, \underline{\mathrm{SD}}=1.7)$.

Of these, $1 \%$ had achieved high school level, $4 \%$ had achieved a school certificate, 51\% had achieved their higher school certificate, 10\% had achieved technical qualifications, $7 \%$ had achieved a diploma, 21\% had achieved a degree, and $6 \%$ had achieved postgraduate qualifications.

Sixty-seven percent of the sample were Australian born, $20 \%$ of the sample were born in English speaking countries, and 13\% of the sample were born in nonEnglish speaking countries. Although the samples recruited for the three studies were slightly skewed toward a more educated and higher socio-economic class, they were overall fairly similar when compared to each other (e.g., educational levels shown in Table 2). Furthermore, each method required participants to complete the task under similar conditions. Once people granted their consent, they were required to write their story, to be interviewed or to fill out a survey in one of the labs at Macquarie University. I carried out all three studies. Hence, although having different subjects participate in each of the studies could indeed in part effect the results, similarities in demographic variables and conditions most probably eliminated some of the potential bias. 
Table 2

$\underline{\text { Percentages of participants for education level achieved }}$

\begin{tabular}{llll}
\hline Educational level achieved & Study 1 & Study 2 & Study 3 \\
\hline High School & $3 \%$ & $0 \%$ & $1 \%$ \\
\hline School Certificate & $9 \%$ & $4 \%$ & $4 \%$ \\
\hline Technical Qualifications & $5 \%$ & $8 \%$ & $10 \%$ \\
\hline Higher School Certificate & $54 \%$ & $52 \%$ & $51 \%$ \\
\hline Degree, diploma & $23 \%$ & $33 \%$ & $28 \%$ \\
\hline Postgraduate & $7 \%$ & $3 \%$ & $6 \%$ \\
\hline
\end{tabular}

Findings. The aim of this study was to examine the utility of a story-writing method in researching young people's 'ideal' selves in respect to their hopes and dreams for the future. It did so by comparing some of the themes generated and the age and sex differences elicited by three methods. Due to the breadth of data collected from each method, it is impossible to provide a detailed account of every finding in this paper. Instead, I present the results that help answer the research question concerning the usefulness of a story-writing method in the analysis of young people's ideal future lives.

\footnotetext{
ANALYSIS

Study 1: Story-writing

In the story-writing method a content analysis was initially carried out to clarify the number and types of dreams and impediments included in their stories. An initial reading indicated the presence of many of the themes revealed in past studies (see Nurmi, 1991). However, the overriding impression was the complexity of the interwoven identities. It became a challenge to code the stories without sacrificing too much of their richness. Given that this study was also used to generate themes for the
} 
following studies, I considered it necessary to document as many of the themes as possible, even if only a few of the participants mentioned them. The main dreams were concerned with, occupation, finances, romance, parenting or having children; travel, leisure, friendship, parents and siblings, religious and political beliefs. These main themes were next broken down into sub-themes, which included further description of the dreams and impediments to these dreams. To check reliability of the coding procedure, $10 \%$ of the data was re-coded by a trained scorer. Inter-coder reliability was high, ranging from Kappa $0.75-1.00$

Logistic regression was used to analyze the data. Initial analyses for the main categories of dreams (occupation, finance, family, marriage, friends, children, leisure, travel, religion and politics) included the independent variables age and sex, and their interactions. The same variables were used in the analysis of the sub-categories. If the interaction was significant, tests of simple effects were carried out, using a conservative $p$ value of 0.025 . If there were any empty cells, the Pearson Chi-square was used to test for simple effects. Significance for the variables age and gender were taken to be at a $p$ value of 0.05 or less.

\section{Study 2: Interviews}

The interview transcripts first were examined for the themes that emerged from the story-writing method. All of the main themes and many of the sub-themes revealed in Study 1 were also uncovered in this study. The transcripts were then re-read to locate any other pertinent themes. Although no new main themes emerged, some additional sub-themes were yielded in this analysis.

Logistic regression was again used in this study. Age and sex and the interaction of age and sex, were once more included in the analyses. If any 
interactions were significant, tests of simple effects were carried out, using a conservative $p$ value of .025 . If there were any empty cells, the Pearson Chi-square analysis was used to test for simple effects. Once more, to check reliability of the coding procedure, $10 \%$ of the data was re-coded by a trained scorer. Inter-coder reliability was again high, ranging from Kappa $0.75-1.00$

\section{Study 3: Questionnaire}

The independent variables age and sex and their interactions were used to analyze the questionnaire. Given that most of the dependent variables were numerical, ANOVAs were used in the analysis. Where dependent variables were categorical, a logistic regression was employed. The main effects employed a $p$ value of 0.05 , while the interactions used a $p$ value of .01

\section{THE DREAMS}

Reported in Table 3 are the frequencies at which participants mentioned the main dreams in Studies 1 and 2 and those who rated these as important in Study 3. The different ways these results were obtained needs to be highlighted here. In the storywriting method, respondents were permitted to write freely about their possible future lives; in the interviews all the main dreams revealed in analysis carried out for Study 1 were used as prompts; whereas in Study 3, one of the questionnaires required respondents to rate their three most important dreams, given the same prompts used in the interview. Therefore, despite some of the interesting comparisons that can be made with these results, the comparisons nevertheless need to be treated with some caution. For example, it could easily be argued that had the participants in the story-writing 
method be given the prompts travel, leisure, friendship, politics and religion, more of the participants might have included these themes in their stories.

Table 3

Frequencies and percentages of participants mentioning the main dreams

\begin{tabular}{lccc}
\hline & Study 1 & Study 2 & Study 3 \\
\hline The dreams & $\begin{array}{c}\text { freq } \\
\mathbf{( \% )}\end{array}$ & $\begin{array}{c}\text { freq } \\
\mathbf{( \% )}\end{array}$ & $\begin{array}{c}\text { freq } \\
\mathbf{( \% )}\end{array}$ \\
\hline Occupational & 264 & 48 & 123 \\
& $(94.3)$ & $(100)$ & $(62)$ \\
\hline Financial & 206 & 48 & 22 \\
& $(73.6)$ & $(100)$ & $(11)$ \\
\hline Romantic & 203 & 35 & 151 \\
Relationships & $(72.5)$ & $(72.9)$ & $(76)$ \\
\hline Parental/having & 166 & 40 & 72 \\
children & $(59.3)$ & $(83.3)$ & $(36)$ \\
\hline Travel Dream & 152 & 45 & 42 \\
& $(54.3)$ & $(93.8)$ & $(21)$ \\
\hline Leisure Dream & 102 & 48 & 20 \\
& $(36.4)$ & $(100)$ & $(10)$ \\
\hline Friendship Dream & 82 & 43 & 43 \\
& $(29.3)$ & $(89.6)$ & $(22)$ \\
\hline Parents/siblings & 47 & 48 & 69 \\
Dream & $(16.8)$ & $(100)$ & $(35)$ \\
\hline Religion/spiritual & 31 & 37 & 34 \\
& $(11.1)$ & $(77.1)$ & $(17)$ \\
\hline Political beliefs & 23 & 37 & 0 \\
& $(8.2)$ & $(77.1)$ & $(0)$ \\
\hline
\end{tabular}

Across all three studies, occupation and romantic relationships were considered the most important and most frequently mentioned dreams. Nurmi (1991) points out, in his review of studies focusing on adolescents' dreams, that occupation is the most frequently mentioned dream, and that romantic relationships also rate fairly highly. It is interesting that when participants were interviewed, religion was rated as the third most important dream (a result atypical of past research). This might be because the interview tapped into 'expected' or 'ought to' selves; Religion is a dream these 
participants felt they ought to be considering for their future lives. Furthermore, in the questionnaire, unlike Study 1, financial dreams were seen as not important, while dreams about parents and siblings were considered reasonably important. Again, this supports the idea that different methods uncover different selves.

Overall, the three studies in general produced similar findings. In every instance where age and sex differences were found they were in the same direction. Despite these similarities, there are a number of important differences. For the sake of brevity, only the differences that contribute to the main research question are reported here.

\section{STUDY 1: GENERATION OF THEMES}

The intention of using the story-method first was to generate themes. This indeed proved to be a wise choice. In addition to the main dreams cited previously, the data revealed numerous sub-themes. For example some of the sub-themes that stemmed from occupational dreams included; becoming successful in one's career, requiring qualifications for one's job, a glamorous job, having a high status, influential job, work that will benefit society, being promoted, a need to balance a relationship and children and a career, lack of abilities as an impediment to one's hoped for job, and a desire to reach the pinnacle of one's career before having children. (There were more sub-themes for occupation not listed here.)

Past research on hopes and dreams has typically focused their research on a more broad level. Few studies have moved beyond the main dreams (such as those outlined in Table 3) to include sub-themes. Therefore, the story-writing method allowed for both a macro and microanalysis of people's dreams. In fact, the sub- 
themes yielded important age and sex differences that would have been missed if the analysis had simply focused on the dreams per se.

The interviews were also useful in the generation of themes. Although fewer dreams emerged in the interview study, it did elicit a few more sub-themes not mentioned in Study 1.

\section{Grand Dreams formed in one's youth}

One of the interesting findings revealed by the story-writing method was that some of the younger participants (17-22 years) described many grandiose dreams for the future. For example, many of them seemed over-ambitious in their career dreams, while some aspired to extraordinary achievements (such as finding a cure for cancer). Others wrote that they would be famous (such as being a supermodel, or in a rock band), while others hoped to marry someone famous. To give some examples of extracts from these types of dreams:

"Currently she is in charge of promoting channel 9's new series and current affairs and is working very closely with the Packer family." (18 year old female)

" After four and a half years in the work force the opportunity arose for him to play soccer for Manchester United which he took." (18 year old male)

"It had been a lot of hard work to get here as the world psychological leader, writer of 3 best sellers." (18 year old female)

"She became acclaimed as a leading author and human rights activist." (19 year old female) 
More specifically, the statistical analysis revealed that older adolescents (1722 years) wrote more than young adults (28- 33 years) about having a glamorous occupation (such as a rock star, supermodel, rock journalist and so forth), $\chi^{2}(1, \underline{N}=$ $280)=7.08, \mathrm{p}<.01$, a benevolent occupation (such as, a human rights activist), $\chi^{2}$ (1, $\underline{\mathrm{N}}=280)=6.55, \mathrm{p}<.01)$, and becoming wealthy, $\chi^{2}(1, \underline{\mathrm{N}}=280)=18.5, \mathrm{p}<.001$. Women wrote more than men about having a powerful and successful partner, $\chi^{2}(1$, $\underline{\mathrm{N}}=280)=8.22, \underline{\mathrm{p}}<.01$. Moreover, younger women wrote more than older women that they would have a high status and influential job, $\chi^{2}(1, \underline{N}=140)=5.53, \underline{p}<$ 0.25). Given that we do not know the abilities and potentialities for these participants, it is difficult to argue that these themes are unrealistic; however, the story writing method does highlight the different tone evident in these participants' personal myths.

This unrealistic tone depicted in some of the younger group's stories is in line with Levinson's concept of the 'Dream'. Levinson (1978) argued that initially the Dream is poorly developed and is not necessarily connected with reality. Consequently, it may start by taking a dramatic or unrealistic form. He also argued that if the Dream is unrelated to the person's life structure it will fade away and lose purpose, and that the 'age thirty transition period' (28-33 years) is a time when people begin to settle down and a 'de-illusioning process' begins (Levinson, Darrow, Klein, Levinson, \& McKee, 1976). If the Dream is not well formed it might become abandoned or re-worked at this stage. This conceptualization is supported by the younger groups' unrealistic ambitions, while the older group was more cognizant of the real opportunities available, and the real impediments to their dreams. For example, the young adults were more concerned than the older adolescents about such things as: a lack of money being an impediment to their career dreams, $\chi^{2}(1, \underline{N}=280)$ $=4.55, p<.05$, the need to provide for their children, $\chi^{2}(1, \underline{\mathrm{N}}=280)=4.29, p<.05$, 
and save money, $\chi^{2}(1, \underline{N}=280)=3.86, p<.05$, and the desire to make financial plans with their partner, $\chi^{2}(1, \underline{\mathrm{N}}=280)=13.56, p<.001$.

These results can be further explained by Elkind's (1974, 1978, Elkind \& Bowen, 1979) notion of the 'personal fable'. Elkind argued that adolescents go through a stage where they develop heroic stories about themselves. He considered that lack of experience in the world partly explained adolescents' egocentricity. This idea of the personal fable could explain why more of the younger group in this present study desired a career where they would be famous and acquire great wealth. Although Elkind argued that the personal fable is more evident during midadolescence, it is clear from Study 1 that some older adolescents and young adults still develop narratives that resemble a personal fable (Whitty, 1997, 1998, in press).

As a corollary of these results, Studies 2 and 3 included a focus on whether younger participants develop less realistic dreams. When we examine these results, a somewhat different picture emerges.

The overall tone evident in the interviews collected in Study 2 appeared to be more serious and somewhat less ambitious than in the story-writing method. Congruous with Study 1, the older adolescents stated more than the young adults about having the dream to become wealthy, $\chi^{2}(1, \underline{\mathrm{N}}=48)=4.18, \underline{\mathrm{p}}<.05$. However, in contrast to Study 1, there were no significant differences for wanting a glamorous occupation or a benevolent occupation. Further, more participants in Study 1 (32.5\%) mentioned a glamorous occupation compared to Study 2 (22.9\%), and more participants in Study $1(22.1 \%)$ mentioned a benevolent occupation compared to Study $2(14.6 \%)$. Moreover, while $13.9 \%$ of participants in the first study wrote about the desire for a powerful and successful partner, and 30\% wrote about having a high status and influential job, these themes were non-existent in the second study. 
An explanation for these differences could be that the interview method elicited different responses from Study 1 because the interviewed participants were faced with an interviewer, or a 'real audience'. Elkind's theory of the personal fable was proposed as an explanation for why some of the older adolescents in Study 1 developed stories involving extraordinary sub-themes. In turn, this theory could be used to explain the differences in responses between Study 1 and 2. In conjunction with the personal fable theory, Elkind argued that adolescents have an exaggerated belief that everyone is watching them. This he termed the 'imaginary audience'. He posited that many adolescents believe that since people are being critical of them, acting outrageously makes little difference. It therefore appears that the story-writing method had some of the participants, especially in the younger group, envisioning this imaginary audience. This might explain why more of the stories in the story-writing method contained grand and extraordinary themes. Furthermore, since participants were faced with a real audience in Study 2 they may have been likely to provide answer they saw as suitable to that audience. For example, in Study 2, more men $(12.5 \%)$ than women $(0 \%)$ stated that they felt advantaged in their careers because of their sex. Given that the participants in Study 2 were interviewed by a woman, this might have appeared the acceptable response. It is poignant that this theme was not mentioned by any of the 280 participants in Study 1 .

Given that the questionnaire presented numerical data, where respondents rated the importance of each theme on a 5-point Likert scale it is a little more difficult to compare results borne out from the questionnaire with the categorical data generated from Studies 1 and 2. Nevertheless, it is noteworthy that age and sex differences elicited for grandiose themes in Study 1 were typically not significant in Study 3 . The only significant difference for the grand themes outlined above was for 
the desire to work in a benevolent occupation. Further, rather than an age difference, in Study 3 women scored higher on this sub-theme than men, $\underline{F}(1,199)=4.88, \underline{p}<$ .05 .

\section{Different Selves}

The main aim of this paper is to elucidate the value of a story-writing approach in the study of young people's 'hoped for futures'. It appears from the results just outlined, along with some further examples given here, that the story-writing method was more successful at elucidating participants' 'idea' or 'hoped for selves', whereas Studies 1 and 3 tapped more into 'actual', 'ought to' or 'expected selves'.

As described above, Study 2 yielded more serious narratives than Study 1 and found participants often justifying their responses to the interviewer. For example, the participants who mentioned that they were advantaged in the workplace because of their gender, and that religion is an important dream (see Table 3), could be projecting their 'ought to' or 'expected' aspects of the self. Furthermore, a unique sub-theme to Study 2 , stated by $10.4 \%$ of the participants, was that a financial dream was not a priority in their lives. Hence, Study 2 elicits a more socially accepted response, that although one might hope to be wealthy or comfortable in the future, it should not be a major concern in one's life.

Once more, the more socially desirable responses evident in Study 3 show that this study was more inclined than Study 1 to measure respondents 'actual', 'expected' or 'ought to' selves. It is noteworthy that while no significant differences in the first two studies were obtained for an occupational dream, Study 3 found that younger participants scored higher than the older for wanting an occupational dream, $\underline{F}(1,199)$ $=6.78, \mathrm{p}<.01$. This dream could have been overemphasized by the younger 
participants in Study 3 since occupation is something younger participants are expected to consider as important. Therefore, in this instance, the questionnaire has probably revealed participants' 'ought to' selves. To give another example, women scored higher than men in Study 3 when asked directly if they were concerned about not finding the right partner, $\underline{F}(1,199)=12.21, \underline{p}<.001$. Moreover, another result exclusive to Study 3 was that women scored higher than men for stating they would work hard at their romantic relationship, $\underline{\mathrm{F}}(1,199)=3.79, \underline{\mathrm{p}}<0.05$. These results appear to be fairly realistic given the many requirements for a perfect partner and the emphasis they placed on their romantic dreams across all three studies. It could be argued that this reflects women's 'actual' concerns.

\section{CONCLUSIONS ABOUT THE UTILITY OF A STORY-WRITING METHOD}

The story-writing approach was very successful at elucidating the complexity of the dream. This study found that the strengths of the story-writing method were its ability to generate themes and to uncover 'ideal' or 'hoped for selves'.

Narrative psychologists propose that when we consider identity we should take into account the stories people have about their lives, rather than how their lives simply actualize. Some have argued for the inclusion in research of both real and unreal aspects of the self (e.g., Bruner, 1986; McAdams, 1993). In fact, Sarbin (1998) has claimed that:

The words real and reality are excluder words. They tell only what something is not, and then only if the context is known...It is important to recognize that real is employed as a term to convince one's self or another that the credibility assigned to an imagining is warranted (p.24). 
It is likely that some of the Study 1 participants' stories will not in reality eventuate. Does this mean that these narratives speak less truth? If the young woman does not eventually finish up in charge of Channel 9's new series and 'work closely with the Packer family,' and if the young man does not become a successful soccer player for Manchester United, does this make their narratives any less authentic, truthful or valid? Simply because narratives appeared to the researcher to be grounded in fantasy does not mean they were not realistic possibilities for these individuals. Perhaps the young man who foresaw being chosen by Manchester United was, in fact, an excellent soccer player who could possibly be chosen to play in one of England's finest football teams? However, even if this story does not actualize, it still contains a certain kind of truth. Although the story-writing method produced some narratives with unrealistic possible futures, this does not mean that these narratives are inauthentic. As Sarbin (1998) argued, if we are only focusing on what is real, we are excluding parts of the narrative. Hence, both 'realistic' and 'unrealistic' narratives were considered to fall within the range of the possible future self. It is also noteworthy that not all participants in Study 1 produced extraordinary stories, but rather the story-writing method provided a greater opportunity for those who would like to envisage grand futures for themselves to do so. It is also interesting that the older adolescents were more inclined to write these stories; perhaps this says something about the way we are socialized to dream.

Although one might argue that the exclusion of prompts was a weakness of this specifically designed story-writing method, it can be counter-argued that this was a strength of the research. Had the participants been promoted with certain dreams, they might have felt less free to write about how they would 'like' to see their future lives. 
In conclusion, this article reveals the need to examine identity formation after mid-adolescence and demonstrates the need for the inclusion of this story-writing method in future research.

\section{References}

Agarwal, A. \& Tiwari, S. (1988). Future orientation: A mediator in temporal coding. International Journal of Psychology, 23, 151-163.

Alexander, M. J., \& Higgins, E. T. (1993). Emotional trade-offs of becoming a parent: How social roles influence self-discrepancy effects. Journal of Personality and Social Psychology, 65, 1259-1269.

Australian Bureau of Statistics. (1997a, May). Australia now - a statistical profile: Education attainment. Canberra, Australian Capital Territory: Author. Retrieved July 2, 1999 from the World Wide Web: http://www.abs.gov.au/

Australian Bureau of Statistics. (1997b, May). Australia now - a statistical profile: Labour employment. Canberra, Australian Capital Territory: Author. Retrieved July 2, 1999 from the World Wide Web: http://www.abs.gov.au/

Bruner, J. (1986). Actual minds, possible worlds. Cambridge, MA, USA: Harvard University Press.

Bruner, J. (1987). Life as narrative. Social Research, 54, 11-32. 
Clasusen, J. A. (1995). Gender, contexts, and turning points in adult's lives. In P. Moen, G. H. Elder, Jr \& K. Lüscher (Eds.), Examining lives in context: Perspectives on the ecology of human development (pp. 365-395). Washington, DC: American Psychological Association.

Cohler, B. J. (1982). Personal narrative and the life course. In P. Baltes \& O.G. Brim (Eds.), Life-span development and behavior (Vol. 4). (pp.205-241). New York: Academic Press.

Crawford, J., Kippax, S., Onyx, J., Gault, U., \& Benton, P. (1992). Emotion and gender: Constructing meaning from memory. London: Sage Publications.

Elkind, D. (1974). A sympathetic understanding of the child, birth to sixteen. Boston: Allyn \& Bacon.

Elkind, D. (1978). Understanding the young adolescent. Adolescence, 13, 127-134.

Elkind, D., \& Bowen, R. (1979). Imaginary audience behavior in children and adolescents. Developmental Psychology, 15, 38-44.

Gillies, P. (1989). A longitudinal study of the hopes and worries of adolescents. Journal of Adolescence, 12, 69-81.

Gillispie, J. M., \& Allport, G. W. (1955). Youth's outlook on the future (a crossnational study). New York: Doubleday \& Company. 
Gergen, K. J., \& Gergen, M. M. (1987). The self in temporal perspectives. In R. P. Abeles (Ed.), Life-span perspectives and social psychology (pp.121-138). Hillsdale, NJ: Erlbaum.

Greene, A. L. (1986). Future-time perspective in adolescence: The present of things future revisited. Journal of Youth and Adolescence, 15, 99-113.

Greene, A. L., \& Wheatley, S. M. (1992). 'I've got a lot to do and I don't think I'll have the time': Gender differences in late adolescents' narratives of the future. Journal of Youth and Adolescence, 21, 667-685.

Haug, F. (1987). Female sexualization: A collective work of memory. London: Verso.

Higgins, E. T., (1987). Self-discrepancy: A theory relating self and affect. Psychological Review, 94, 319-340.

Howard, G. S. (1991). Culture tales: A narrative approach to thinking, cross-cultural psychology, and psychotherapy. American Psychologist, 46, 187-197.

Kalakoski, V., \& Nurmi, J. E. (1995). Identity and educational transitions: Age differences in adolescent exploration and commitment related to education, occupation and family. University of Helsinki, Finland.

Levinson, D. J. (1978). The seasons of a man's life. New York: Knopf. 
Levinson, D. J. (1996). The seasons of a woman's life. New York: Knopf.

Levinson, D. J., Darrow, C. M., Klein, E. B., Levinson, M. H., \& McKee, B. (1976). Periods in the adult development of men: Ages 18 to 45. The Counseling Psychologist, 6, 21-25.

Mair, M. (1988). Psychology as storytelling. International Journal of Personal Construct Psychology, 1, 125-137.

Mair, M (1990). Telling psychological tales. International Journal of Personal Construct Psychology, 3, 121-135.

Markus, H., \& Nurius, P. (1986). Possible selves. American Psychologist, 41, 954969.

Markus, H., \& Nurius, P. (1987). Possible selves: The interface between motivation and the self-concept. In K. Yardly \& T. Honess (Eds.), Self and identity: Psychosocial perspectives (pp.157-172). Chichester, UK: Wiley.

McAdams, D. P. (1989). The development of a narrative identity. In D. M. Buss, \& N. Cantor (Eds.), Personality psychology: Recent trends and emerging directions (pp.160-174). New York: Springer-Verlag.

McAdams, D. P. (1993). Stories we live by: Personal myths and the making of the self. New York: William Morrow and Company Inc. 
McAdams, D. P. (1996). Personality, modernity, and the storied self: A contemporary framework for studying persons. Psychological Inquiry, 7, 295-321.

Mönks, F. (1968). Future time perspective in adolescents. Human Development, 11, 107-123.

Neisser, U., \& Fivush, R. (Eds.). (1994). The remembering self: Construction and accuracy in the self-narrative. New York: Cambridge University Press.

Nurmi, J. (1991). How do adolescents see their future? A review of the development of future orientation and planning. Developmental Review, 11, 1-59.

Nurmi, J., Poole, M. E., \& Kalakoski, V. (1994). Age differences in adolescent futureoriented goals, concerns, and related temporal extension in different sociocultural contexts. Journal of Youth and Adolescence, 23, 471-487.

Nurmi, J., Poole, M. E., \& Seginer, R. (1995). Tracks and transitions: A comparison of adolescent future-oriented goals, explorations, and commitments in Australia, Israel, and Finland. International Journal of Psychology, 30, 355-375.

Nurmi, J., Seginer, R., \& Poole, M. (1990). Future-orientation questionnaire. University of Helsinki. 
Ochberg, R. L. (1994). Life stories and storied lives. In A. Lieblich \& R. Josselson (Eds.), Exploring identity and gender: the narrative study of lives (Vol. 2). (pp. 113144). USA: Sage.

Polkinghorne, D. P. (1988). Narrative knowing and the human sciences. Albany, NY: SUNY Press.

Poole, M. E. (1983). Youth: Expectations and transitions. Melbourne: Routledge \& Keegan Paul.

Poole, M. E., \& Cooney, G. H. (1987). Orientations to the future: A comparison of adolescents in Australia and Singapore. Journal of Youth and Adolescence, 16, 129151.

Ricoeur, P. (1984). Time and Narrative (K. McLaughlin \& D. Pellauer Trans.). Chicago: University of Chicago Press.

Roberts, P., \& Newton, P. M. (1987). Levinsonian studies of women's adult development. Psychology and Aging, 2, 154-163.

Sarbin, T. R. (1986). The narrative as the root metaphor for psychology. In T. R. Sarbin (Ed.), Narrative Psychology: The storied nature of human conduct (pp.3-21). New York: Praeger.

Seginer, R. (1992). Future orientation: Age-related differences among adolescent females. Journal of Youth and Adolescence, 21, 421-437. 
Sarbin, T. R. (1998). Believed-in imaginings: A narrative approach. In J. de Rivera \& T. R. Sarbin (Eds.), Believed-in imaginings: The narrative construction of reality. (pp. 15-30). USA: American Psychological Association.

Strauman, T. J., \& Higgins, E. T. (1987). Automatic activation of self-discrepancies and emotional syndromes: When cognitive structures influence affect. Journal of Personality and Social Psychology, 53, 1004-1014.

Trommsdorff, G., Lamm, H., \& Schmidt, R. W. (1979). A longitudinal study of adolescents' future orientation (time perspective). Journal of Youth and Adolescence, $8,131-147$.

Whitty, M. (1997). Young male's and female's narratives of their plans for the future. Poster session presented at the 10th Australiasian Human Development Conference, 10-12th July, 1997.

Whitty, M. (1998). Young men and women's narratives of their plans for the future. Paper presented at the Storied Lives-Lived Stories. The Seventh International Conferences on Narrative November 6-8, 1998.

Whitty, M. (in press). The myth of the superwoman: comparing young men and women's stories of their future lives. Journal of Family Studies. 